\title{
PENGEMBANGAN SISTEM MANAJEMEN MUTU SEBAGAI ALAT KONTROL PRODUKTIVITAS KINERJA PEKERJA STRUKTUR BERBASIS INEFFECTIVE WORK (STUDI KASUS : PROYEK PADINA SOHO \& RESIDENCE)
}

\author{
Pratiwi Setyaning Putri ${ }^{1}$, Hastanto $\mathrm{SM}^{2}$, Sriyono D Siswoyo ${ }^{3}$ \\ ${ }^{1}$ Sekolah Tinggi Teknik-PLN \\ ${ }^{2}$ Sekolah Tinggi Teknik-PLN \\ ${ }^{3}$ Sekolah Tinggi Teknik-PLN \\ E-mail : pratiwi@sttpln.ac.id
}

\begin{abstract}
This study aims to analyze the productivity of structural workers in the Padina Soho \& Residence Project and make the Quality Management System based on ineffective work as a tool to control the productivity of structural workers' performance. Data collection techniques are carried out by field observations and interviews. The method used to measure the level of productivity is work sampling. The productivity measure obtained from this analysis is the labor utilization rate (LUR). In this study there are three types of structural work observed, formwork, reinforcement work, and casting work. Furthermore, the development of the Quality Management System is based on ineffective work as a tool to control the productivity of structural workers' performance.
\end{abstract}

Keywords : Quality Management System, Ineffective Work

\begin{abstract}
ABSTRAK
Penelitian ini bertujuan untuk menganalisa produktivitas para pekerja struktur pada Proyek Padina Soho \& Residence dan membuat Sistem Manajemen Mutu berbasis ineffective work sebagai alat kontrol produktivitas kinerja pekerja struktur. Teknik pengumpulan data dilakukan dengan observasi lapangan dan wawancara. Metode yang digunakan untuk mengukur tingkat produktivitas adalah work sampling. Ukuran produktivitas yang didapat dari analisa ini adalah labour utilization rate (LUR). Pada penelitian ini terdapat tiga jenis pekerjaan struktur yang diamati yaitu pekerjaan bekisting, pekerjaan pembesian, dan pekerjaan pengecoran. Selanjutnya dilakukan pengembangan Sistem Manajemen Mutu berbasis ineffective work sebagai alat kontrol produktivitas kinerja pekerja struktur.
\end{abstract}

Kata kunci: Sistem Manajemen Mutu, Pekerjaan yang tidak efektif 


\section{PENDAHULUAN}

Seiring meningkatnya kebutuhan manusia terhadap Persaingan usaha jasa konstruksi pada era globalisasi yang sangat ketat, dengan hadirnya kontraktor asing ke pasar konstruksi juga tuntutan transparansi sebagai ciri dari globalisasi akan sangat menguat. Dengan demikian kita tidak bisa menghindar dari kondisi global. Maka dari itu pola berpikir lokal akan berubah menjadi pola berpikir global. Sering ditemui suatu kegiatan proyek konstruksi terlambat dalam pelaksanaannya atau tidak sesuai dengan jadual yang telah disepakati bersama dalam perjanjian kontrak. Kerterlambatan proyek dikarenakan beberapa faktor antara lain disebabkan oleh produktivitas dari tenaga kerja yang ada dalam kegiatan proyek konstruksi tersebut.

Kesenjangan yang terjadi antara tingkat produktivitas aktual dan rencana (productivity gap) merupakan masalah produktivitas yang harus dievaluasi dan dicari akar penyebab yang menimbulkan kesenjangan produktivitas tersebut. Setelah dilakukan evaluasi selanjutnya dapat direncanakan kembali target produktivitas yang akan dicapai baik dalam jangka pendek maupun jangka panjang. Pada penelitian ini pengukuran produktivitas menggunakan metode work sampling sebagai alat monitoring-nya. Pengukuran produktivitas dilakukan untuk mengetahui seberapa besar produktivitas tenaga kerja pada pekerjaan bangunan konstruksi agar bisa dijadikan acuan pada proyek sejenis dimasa yang akan datang.

Adapun maksud dan tujuan dari penelitian yang dilakukan oleh peneliti adalah :

1. Mengetahui kegiatan yang dilakukan pada pekerjaan struktur beton pada proyek Padina Soho \& Residence.

2. Mengetahui produktivitas pada pekerjaan struktur beton pada proyek Padina Soho \& Residence.

3. Mengetahui cara membuat Sistem Manajemen Mutu untuk mengontrol produktivitas kinerja pekerja struktur pada proyek Padina Soho \& Residence

Sebagai faktor novelty (keterbaruan penelitian) pada penelitian ini adalah, penelitian ini merupakan pengembangan dari penelitian terdahulu dengan konsep utama yaitu pengembangan sistem manajemen mutu berbasis ineffective work disertai dengan respon untuk mengurangi inefektivitas pekerja struktur yang dapat dilakukan dalam pekerjaan struktur dengan mengambil objek penelitian pada proyek Padina Soho \& Residence. Pemilihan objek ini dikarenakan langkah penyempurnaan dari proses pekerjaan struktur eksisting sehingga dapat meningkatkan nilai produktivitas pekerja

struktur.

Tabel 1. Pengelompokan Kegiatan Pekerja Struktur

\begin{tabular}{|l|l|l|l|}
\hline \multirow{2}{*}{ Kategori } & \multicolumn{3}{|c|}{ Kegiatan } \\
\cline { 2 - 4 } & \multicolumn{1}{|c|}{ Bekisting } & \multicolumn{1}{c|}{ Pembesian } & \multicolumn{1}{c|}{ Pengecoran } \\
\hline Effective & Pekerjaan langsung & Pekerjaan langsung & Pekerjaan langsung: \\
Work & & & 1. Pemadatan beton \\
(Productive) & & & 2. Penyemaian beton \\
& & & 3. Pengetesan beton \\
\hline Essential & 1. Transportasi & 1.Pabrikasi besi & 1. Transportasi beton di \\
Contribury & plywood di area & 2. Transportasi material & area \\
Work (Semi & 2. Membawa perancah & besi & 2.Memberi/menerima \\
Productive) & 3. Setting perancah dan & 3. Memberi atau & perintah \\
& plywood & menerima perintah & 3. Operator crame \\
& 4. Memberi atau & 4. Oprator crane & 4.Menuang beton (plat) \\
& menerima perintah & 5. Perakitan besi & 5.Finishing beton \\
& 5. Operator crane & 6. Pembersihan & (plat) \\
& 6.Shoring dan bracing & 7. Minor cont work & 6. Finishing beton (plat) \\
& 7.Minor cont. work & & 7.Curing \\
\hline
\end{tabular}

\begin{tabular}{|l|l|l|l|}
\hline \multirow{2}{*}{ Kategori } & \multicolumn{3}{|c|}{ Kegiatan } \\
\cline { 2 - 4 } & \multicolumn{1}{|c|}{ Bekisting } & \multicolumn{1}{|c|}{ Pembesian } & \multicolumn{1}{|c|}{ Pengecoran } \\
\hline Ineffective & 1. Berjalan dengan & 1. Berjalan dengan tangan & 1.Duduk-duduk \\
work (non & tangan kosong & kosong & 2. Melihat-lihat \\
productive) & 2.Membawa material & 2.Membawa material & 3. Merokok \\
& 3.Menunggu material & 3.Menunggu material & 4. Minum \\
& atau perintah & atau perintah & 5.Menunggu beton \\
& 4.Menunggu & 4.Menunggu pekerjaan & kering \\
& pekerjaan yang lain & yang lain & 6.Delay karena cuaca \\
& 5.Delay karena cuaca & 5. Waktu pribadi & \\
& 6.Delay karena crane & 6.Delay karena cuaca & \\
& 7.Duduk dan minum & 7.Delay karena crane & \\
& & 8.Duduk dan minum & \\
& &
\end{tabular}

Observasi pengukuran produktivitas pekerja dibutuhkan untuk menghemat waktu proyek sebagaimana juga dengan biaya proyek tanpa mengesampingkan kualitas kerja. Manajemen yang tidak efisien pada sumber daya konstriksi dapat menghasilkan produktifitas yang rendah sedangkan 
manajemen yang baik pada sumber daya proyek konstruksi dapat menghasilkan pengehematan waktu dan biaya).

Dalam bidang konstruksi, pengertian produktivitas tersebut biasanya dihubungkan dengan produktivitas pekerja dan dapat dijabarkan sebagai perbandingan antara hasil kerja dan jam kerja. Pengukuran produktivitas tenaga kerja seperti diatas sulit dilakukan secara akurat dan memerlukan tenaga dan biaya yang besar. Oleh karena itu pengukuran produktivitas tenaga kerja di konstruksi dapat dilakukan dengan metode-metode pendekatan, salah satunya adalah metode work sampling.

Work sampling secara umum dapat dikatakan sebagai suatu teknik dimana banyak dilakukan pengamatan cepat dalam periode waktu tertentu dari suatu kelompok kerja, mesin atau proses. Pada penelitian ini yang menjadi fokus adalah pekerja. Work sampling dapat dibagi menjadi tiga pendekatan:

1. Field rating

2. Five minute rating

3. Productivity rating

Field rating adalah metode yang paling mudah dengan cara mencatat secara acak kondisi pekerja sedang melaksanakan pekerjaan atau tidak. Field rating didefinisikan sebagai.

$$
\text { Field rating }=\frac{\text { Jumlah pekerja yang sedang bekerja }}{\text { Jumlah total pekerja }}+10 \%
$$

Five-minute rating, teknik ini berbeda dengan work sampling yang lain yaitu dengan cara mengamati suatu kegiatan dengan waktu yang singkat, teknik ini tidak cocok untuk pengamatan dalam kelompok besar.

Productivty rating, dikelompokkan menjadi tiga jenis kegiatan yaitu :

1. Effective work (productive) adalah pekerjaan dimana kegiatan pekerja berkaitan langsung dengan proses konstruksi yang berperan langsung terhadap hasil akhir.

2. Essential contributory work (semi productive) adalah kegiatan yang tidak berpengaruh langsung terhadap hasil akhir tetapi pada umumnya dibutuhkan dalam menjalankan suatu operasi.

3. Ineffective work (non productive) adalah kegiatan pekerja yang menganggur atau melakukan sesuatu yang tidak berkaitan langsung dengan pekerjaan yang dilakukan.

Setelah pengamatan selesai dilakukan perhitungan di masing-masing jenis kegiatan. Cara menghitung berapa besar tingkat keefektifan (produktivitas) pekerja digunakan metode pendekatan yang disebut Labour Utilization Rate (LUR). Menurut (Oglesby 1989) perhitungan nilai LUR diperoleh dengan formula berikut :

$$
L U R=\frac{\text { Effective }+1 / 4 \text { Essential contributory }}{\text { Total pengamatan }}
$$

Dimana effective dan essential contributory adalah jumlah pekerja yang melakukan effective work dan essential contributory work secara berturut-turut dan jumlah total pengamatan adalah jumlah total pekerja dari ketiga jenis kegiatan (effective + essential contributory + ineffective works). Alasan menggunakan metode work sampling (productivity rating) karena metode ini dianggap paling mudah dilaksanakan dengan cara pengamatan langsung di lapangan tanpa mengganggu pekerja yang sedang bekerja dan cocok untuk pekerjaan yang bersifat kelompok. Pengamatan dilakukan pada waktu tertentu setiap saat pekerja sedang bekerja.

Manajemen mutu proyek meliputi proses untuk memasukkan ketentuan kualitas organisasi yang meliputi perencanaan, pengaturan, dan pengendalian proyek dan mutu produk membutuhkan seiring 
dengan penilaian obyektif dari seluruh stakeholder. Manajemen mutu proyek juga mendukung keberlanjutan proses perkembangan kegiatan sebagaimana bagian dari kinerja organisasi'

\section{METODOLOGI PENELITIAN}

Dalam menjawab rumusan masalah, ada beberapa tahapan penelitian yang penulis lakukan, seperti digambarkan pada Gambar 1 berikut ini.

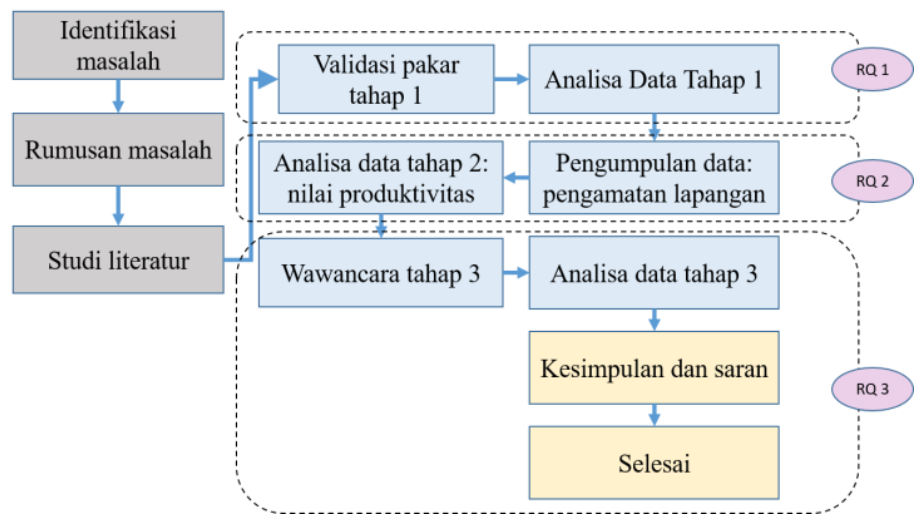

Gambar 1. Tahapan Penelitian

\section{HASIL DAN PEMBAHASAN}

\section{Kegiatan Pada Pekerjaan Struktur Beton Proyek Padina Soho \& Residence}

Hasil validasi di lapangan mengenai kegiatan pada pekerjaan struktur beton proyek Padina Soho \& Residence menunjukkan bahwa teridentifikasi terdapat 3 proses bisnis dengan 18 jumlah aktivitas didalamnya. Hasil temuan kegiatan proses pekerjaan struktur beton proyek Padina Soho \& Residence ditunjukkan pada Tabel 2.

Tabel 2. Kegiatan Pekerjaan Struktur Beton Proyek Padina Soho \& Residence

\begin{tabular}{|c|c|c|c|}
\hline Pekerjaan & \multicolumn{2}{|c|}{ Jenis Kegiatan } & Var \\
\hline \multirow{6}{*}{ Bekisting } & Effective work & Pekerjaan langsung & $\mathrm{X} 1$ \\
\hline & \multirow{2}{*}{ Contributory work } & Membawa material \& alat & $\mathrm{X} 2$ \\
\hline & & Instruksi & $\mathrm{X} 3$ \\
\hline & \multirow{3}{*}{ Ineffective work } & Berjalan dengan tangan kosong & $\mathrm{X} 4$ \\
\hline & & Menganggur & $\mathrm{X} 5$ \\
\hline & & Waktu pribadi & $\mathrm{X} 6$ \\
\hline \multirow{6}{*}{ Pembesian } & Effective work & Pekerjaan langsung & $\mathrm{X} 7$ \\
\hline & \multirow{2}{*}{ Contributory work } & Membawa material \& alat & $\mathrm{X} 8$ \\
\hline & & Instruksi & $\mathrm{X} 9$ \\
\hline & \multirow{3}{*}{ Ineffective work } & Berjalan dengan tangan kosong & $\mathrm{X} 10$ \\
\hline & & Menganggur & $\mathrm{X} 11$ \\
\hline & & Waktu pribadi & $\mathrm{X} 12$ \\
\hline \multirow{6}{*}{ Pengecoran } & Effective work & Pekerjaan langsung & $\mathrm{X} 13$ \\
\hline & \multirow{2}{*}{ Contributory work } & Membawa material \& alat & $\mathrm{X} 14$ \\
\hline & & Instruksi & $\mathrm{X} 15$ \\
\hline & \multirow{3}{*}{ Ineffective work } & Berjalan dengan tangan kosong & $\mathrm{X} 16$ \\
\hline & & Menganggur & $\mathrm{X} 17$ \\
\hline & & Waktu pribadi & $\mathrm{X} 18$ \\
\hline
\end{tabular}




\section{Produktivitas Pada Pekerjaan Struktur Beton Proyek Padina Soho \& Residence}

Pada pengumpulan data tahap ini kegiatan pekerjaan struktur yang teah terbagi menjadi 3 kategori yaitu effective work, contributory work, ineffective work dan pengumpulan data di lapangan dilakukan dengan metode work sampling. Hasil temuan pada subbab ini ditunjukkan pada Tabel 3.

Tabel 3. Produktivitas Pekerjaan Struktur Beton

\begin{tabular}{|c|c|c|c|c|}
\hline Pekerjaan & \multicolumn{2}{|c|}{ Jeris Kegiatan } & Var & $\begin{array}{c}\text { Jumiah } \\
\text { Pengamatan }\end{array}$ \\
\hline \multirow{6}{*}{ Belcisting } & Effective work & Pekcrjaan langoung & $\mathrm{X} 1$ & 144 \\
\hline & \multirow{2}{*}{ Contributary wark } & Menbawa material \& alat & $\mathrm{X} 2$ & 94 \\
\hline & & Instruksi & $\mathrm{x} 3$ & 9 \\
\hline & \multirow{3}{*}{ Insffect ive wark } & Berialan dengan tarzan kosorr & $\mathrm{x} 4$ & 24 \\
\hline & & Menganggur & $\mathrm{X} 5$ & 64 \\
\hline & & Waltu pribadi & $\mathrm{x} 6$ & 19 \\
\hline \multirow{6}{*}{ Penbesian } & Effective work & Pekejaan langoung & $\mathrm{X} 7$ & 154 \\
\hline & \multirow{2}{*}{ Contributary wark } & Menbawa material \& alat & $\mathrm{xB}$ & 124 \\
\hline & & Instruksi & $\mathrm{xg}$ & 9 \\
\hline & \multirow{3}{*}{ Insffect ive wark } & Berjalan dengan tarzan kosong & $\mathrm{X} 10$ & 39 \\
\hline & & Merrangagur & $\mathrm{X} 11$ & 79 \\
\hline & & Waltu pribadi & $\mathrm{X} 12$ & 24 \\
\hline \multirow{6}{*}{ Pergecoran } & Effective work & Pelceriazn langaung & $\mathrm{X} 13$ & 44. \\
\hline & \multirow{2}{*}{ Contributary wark } & Menbawa material \& alat & $\mathrm{X} 14$ & 29 \\
\hline & & Instrulasi & $\mathrm{X} 15$ & 4 \\
\hline & \multirow{3}{*}{ Insffect ive wark } & Berjalan dengan targan kosorg & $\mathrm{X} 16$ & 4 \\
\hline & & Menzangaur & $\mathrm{X} 17$ & 19 \\
\hline & & Walktu pribadi & $\mathrm{X} 18$ & 3 \\
\hline
\end{tabular}

\section{Pengembangan Sistem Manajemen Mutu Pekerja Struktur Proyek Padina Soho \& Residence}

Berdasarkan hasil temuan pengamatan produktivitas pada pekerjaan struktur beton tersebut dilakukan pengumpulan data ineffective work untuk selanjutnya dapat dilakukan respon berupa tindakan preventif dan tindakan korektif yang dapat dilakukan untuk mengurangi penyebab dan dampak yang dapat memperkecil nilai produktivitas. Kegiatan ineffective work yang selanjutnya dijadikan dasar dalam pengembangan SMM (Sistem Manajemen Mutu) ditunjukkan pada Tabel 4.

Tabel 4. Produktivitas Ineffective Work Pekerjaan Struktur Beton

\begin{tabular}{|r|l|l|l|r|r|}
\hline Peringkat & Pekerjaan & \multicolumn{1}{|c|}{ Uraian Kegiatan } & Var & $\begin{array}{c}\text { Jumlah } \\
\text { Pengamatan }\end{array}$ & $\begin{array}{c}\text { Proporsi } \\
(\%)\end{array}$ \\
\hline 1 & Pengecoran & Menganggur & X17 & 19 & 18,45 \\
\hline 2 & Pembesian & Menganggur & X11 & 79 & 18,41 \\
\hline 3 & Bekisting & Menganggur & X5 & 64 & 18,08 \\
\hline 4 & Pembesian & Berjalan dengan tangan kosong & X10 & 39 & 9,09 \\
\hline 5 & Bekisting & Berjalan dengan tangan kosong & X4 & 24 & 6,78 \\
\hline 6 & Pembesian & Waktu pribadi & X12 & 24 & 5,6 \\
\hline 7 & Bekisting & Waktu pribadi & X6 & 19 & 5,37 \\
\hline 8 & Pengecoran & Berjalan dengan tangan kosong & X16 & 4 & 3,88 \\
\hline 9 & Pengecoran & Waktu pribadi & X18 & 3 & 2,91 \\
\hline
\end{tabular}


JURNAL FORUM MEKANIKA

Vol. 7, No. 2, November 2018, P-ISSN 2356-1491, E-ISSN xxxx-Xxxx

Tindakan preventif dan korektif yang merupakan hasil dari pengembangan ditunjukkan pada Tabel 5.

Tabel 5. Analisis Tindakan Pengembangan

\begin{tabular}{|c|c|c|c|c|c|c|}
\hline & \multirow{2}{*}{ Kategori Pekerjaan } & \multicolumn{2}{|r|}{ Ineffective work } & \multirow{2}{*}{ SMM Pekerjaan Konstruksi } & \multirow{2}{*}{ Tindakan Pengembangan } \\
\hline & & & Var & Peristiwa ineffective worl & & \\
\hline \multicolumn{7}{|c|}{ Tindakan Preventif } \\
\hline \multirow[t]{2}{*}{ TP1 } & $\begin{array}{l}\text { Memastikan ketersediaan } \\
\text { material di lokasi proyek }\end{array}$ & Pekerjaan Pengecoran & $\mathrm{X} 16$ & \begin{tabular}{|l|}
$\begin{array}{l}\text { Berjalan dengan tangan } \\
\text { kosong }\end{array}$ \\
\end{tabular} & IK Pengecoran & $\begin{array}{l}\text { Perencanaan ketersediaan dan } \\
\text { mobilisasi material }\end{array}$ \\
\hline & & Pekerjaan Pengecoran & X17 & Menganggur & IK Pengecoran & $\begin{array}{l}\text { Perencanaan ketersediaan dan } \\
\text { mobilisasi material }\end{array}$ \\
\hline \multirow[t]{2}{*}{ TP2 } & $\begin{array}{l}\text { Survey ketersediaan material di } \\
\text { pasar }\end{array}$ & Pekerjaan Pengecoran & $\mathrm{X} 16$ & $\begin{array}{l}\text { Berjalan dengan tangan } \\
\text { kosong }\end{array}$ & IK Pengecoran & $\begin{array}{l}\text { Perencanaan ketersediaan dan } \\
\text { mobilisasi material }\end{array}$ \\
\hline & & Pekerjaan Pengecoran & $\mathrm{X} 17$ & Menganggur & IK Pengecoran & $\begin{array}{l}\text { Perencanaan ketersediaan dan } \\
\text { mobilisasi material }\end{array}$ \\
\hline \multirow[t]{2}{*}{ TP3 } & $\begin{array}{l}\text { Memberikan pengarahan dan } \\
\text { sosialisasi }\end{array}$ & Pekerjaan Pembesian & $\mathrm{X} 10$ & $\begin{array}{l}\text { Berjalan dengan tangan } \\
\text { kosong }\end{array}$ & IK Pembesian & $\begin{array}{l}\text { Menambah kegiatan pengarahan } \\
\text { dan sosialisasi }\end{array}$ \\
\hline & & Pekerjaan Pembesian & $\mathrm{X} 11$ & Menganggur & IK Pembesian & $\begin{array}{l}\text { Menambah kegiatan pengarahan } \\
\text { dan sosialisasi }\end{array}$ \\
\hline TP4 & Memberikan insentif & Pekerjaan Bekisting & $\mathrm{X} 5$ & Menganggur & SOP Pekerjaan Struktur & $\begin{array}{l}\text { Perencanaan reward \& } \\
\text { punishment yang didapatkan } \\
\text { pekerja apabila pekerjaan tercapai }\end{array}$ \\
\hline TP5 & $\begin{array}{l}\text { Memberikan waktu libur apabila } \\
\text { pekerjaan selesai lebih cepat }\end{array}$ & Pekerjaan Bekisting & $\mathrm{X} 5$ & Menganggur & SOP Pekerjaan Struktur & $\begin{array}{l}\text { Perencanaan reward \& } \\
\text { punishment yang didapatkan } \\
\text { pekerja apabila pekerjaan tercapai }\end{array}$ \\
\hline TP6 & $\begin{array}{l}\text { Meningkatkan kemampuan } \\
\text { pekerja }\end{array}$ & Pekerjaan Bekisting & $\mathrm{X} 4$ & \begin{tabular}{|l|}
$\begin{array}{l}\text { Berjalan dengan tangan } \\
\text { kosong }\end{array}$ \\
\end{tabular} & IK Bekisting & $\begin{array}{l}\text { Menambah kegiatan pengarahan } \\
\text { dan sosialisasi }\end{array}$ \\
\hline TP7 & Memberikan pelatihan & Pekerjaan Bekisting & $\mathrm{X} 4$ & $\begin{array}{l}\text { Berjalan dengan tangan } \\
\text { kosong }\end{array}$ & IK Bekisting & $\begin{array}{l}\text { Menambah kegiatan pengarahan } \\
\text { dan sosialisasi }\end{array}$ \\
\hline TP8 & $\begin{array}{l}\text { Membuat perencanaan komposisi } \\
\text { tenaga kerja }\end{array}$ & Pekerjaan Pembesian & $\mathrm{X} 12$ & Waktu pribadi & SOP Pekerjaan Struktur & Membuat perencanaan SDM \\
\hline TP9 & Cek kesehatan berkala & Pekerjaan Bekisting & X6 & Waktu pribadi & SOP Pekerjaan Struktur & $\begin{array}{l}\text { Perencanaan hak dan kewajiban } \\
\text { pekerja }\end{array}$ \\
\hline TP10 & $\begin{array}{l}\text { Memberikan waktu istirahat yang } \\
\text { cukup }\end{array}$ & Pekerjaan Bekisting & $\mathrm{X} 6$ & Waktu pribadi & SOP Pekerjaan Struktur & $\begin{array}{l}\text { Perencanaan hak dan kewajiban } \\
\text { pekerja }\end{array}$ \\
\hline
\end{tabular}

\begin{tabular}{|c|c|c|c|c|c|c|}
\hline TP11 & Menyediakan katering proyek & Pekerjaan Bekisting & $\mathrm{X} 6$ & Waktu pribadi & SOP Pekerjaan Struktur & $\begin{array}{l}\text { Perencanaan hak dan kewajiban } \\
\text { pekerja }\end{array}$ \\
\hline TP12 & $\begin{array}{l}\text { Memberikan pelatihan } \\
\text { leadership terhadap ketua tim }\end{array}$ & Pekerjaan Pengecoran & $\mathrm{X} 18$ & Waktu pribadi & IK Pengecoran & $\begin{array}{l}\text { Menambah pengarahan } \\
\text { leadership terhadap ketua tim }\end{array}$ \\
\hline & $\begin{array}{l}\text { Mengalokasikan SDM untuk } \\
\text { bertugas melakukan pengawasan }\end{array}$ & Pekerjaan Pengecoran & X18 & Waktu pribadi & IK Pengecoran & Melakukan review kinerja \\
\hline \multicolumn{7}{|c|}{ Tindakan Korektif } \\
\hline \multirow[t]{6}{*}{ TK1 } & Membuat daftar supplier material & Pekerjaan Pembesian & $\mathrm{X} 10$ & $\begin{array}{l}\text { Berjalan dengan tangan } \\
\text { kosong }\end{array}$ & IK Pembesian & $\begin{array}{l}\text { Perencanaan ketersediaan dan } \\
\text { mobilisasi material }\end{array}$ \\
\hline & & Pekerjaan Pembesian & $\mathrm{X} 11$ & Menganggur & IK Pembesian & $\begin{array}{l}\text { Perencanaan ketersediaan dan } \\
\text { mobilisasi material }\end{array}$ \\
\hline & & Pekerjaan Pembesian & $\mathrm{X} 12$ & Waktu pribadi & IK Pembesian & $\begin{array}{l}\text { Perencanaan ketersediaan dan } \\
\text { mobilisasi material }\end{array}$ \\
\hline & & Pekerjaan Pengecoran & $\mathrm{X} 16$ & $\begin{array}{l}\text { Berjalan dengan tangan } \\
\text { kosong }\end{array}$ & IK Pengecoran & $\begin{array}{l}\text { Perencanaan ketersediaan dan } \\
\text { mobilisasi material }\end{array}$ \\
\hline & & Pekerjaan Pengecoran & $\mathrm{X} 17$ & Menganggur & IK Pengecoran & $\begin{array}{l}\text { Perencanaan ketersediaan dan } \\
\text { mobilisasi material }\end{array}$ \\
\hline & & Pekerjaan Pengecoran & $\mathrm{X} 18$ & Waktu pribadi & IK Pengecoran & $\begin{array}{l}\text { Perencanaan ketersediaan dan } \\
\text { mobilisasi material }\end{array}$ \\
\hline TK2 & $\begin{array}{l}\text { Memberikan sosialisasi atau } \\
\text { pelatihan cara penggunaan alat } \\
\text { kerja }\end{array}$ & Pekerjaan Pembesian & X11 & Menganggur & IK Pembesian & $\begin{array}{l}\text { Menambah kegiatan pengarahan } \\
\text { dan sosialisasi }\end{array}$ \\
\hline
\end{tabular}


JURNAL FORUM MEKANIKA

Vol. 7, No. 2, November 2018, P-ISSN 2356-1491, E-ISSN xxxx-Xxxx

Tabel 5. Analisis Tindakan Pengembangan (Lanjutan)

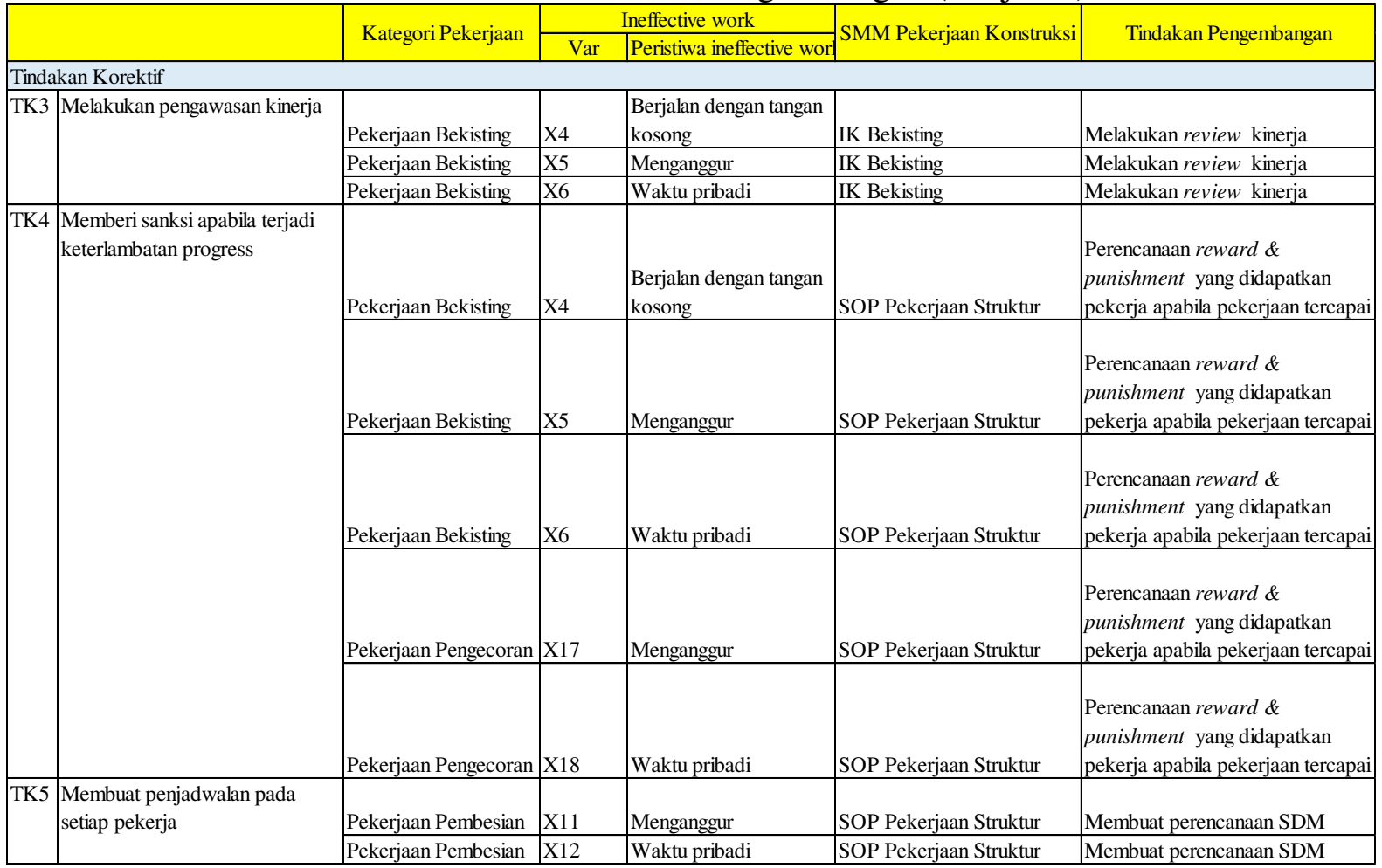

\begin{tabular}{|l|l|l|l|l|l|l|}
\hline TK6 & Menyediakan ruang istirahat & Pekerjaan Bekisting & $\mathrm{X} 4$ & $\begin{array}{l}\text { Berjalan dengan tangan } \\
\text { kosong }\end{array}$ & SOP Pekerjaan Struktur & $\begin{array}{l}\text { Perencanaan hak dan kewajiban } \\
\text { pekerja }\end{array}$ \\
\cline { 3 - 7 } & & Pekerjaan Bekisting & $\mathrm{X} 5$ & Menganggur & SOP Pekerjaan Struktur & $\begin{array}{l}\text { Perencanaan hak dan kewajiban } \\
\text { pekerja }\end{array}$ \\
\cline { 3 - 7 } & Pekerjaan Bekisting & $\mathrm{X} 6$ & Waktu pribadi & SOP Pekerjaan Struktur & $\begin{array}{l}\text { Perencanaan hak dan kewajiban } \\
\text { pekerja }\end{array}$ \\
\hline TK7 & $\begin{array}{l}\text { Menyediakan tim medis yang } \\
\text { berjaga }\end{array}$ & Pekerjaan Bekisting & $\mathrm{X} 4$ & $\begin{array}{l}\text { Berjalan dengan tangan } \\
\text { kosong }\end{array}$ & SOP Pekerjaan Struktur & $\begin{array}{l}\text { Menambah penanggung jawab tim } \\
\text { medis }\end{array}$ \\
\cline { 3 - 6 } & Pekerjaan Bekisting & $\mathrm{X} 5$ & Menganggur & SOP Pekerjaan Struktur & $\begin{array}{l}\text { Menambah penanggung jawab tim } \\
\text { medis }\end{array}$ \\
\cline { 3 - 6 } & Pekerjaan Bekisting & $\mathrm{X} 6$ & Waktu pribadi & SOP Pekerjaan Struktur & $\begin{array}{l}\text { Menambah penanggung jawab tim } \\
\text { medis }\end{array}$ \\
\hline
\end{tabular}

\begin{tabular}{|c|c|c|c|c|c|c|}
\hline \multirow[t]{3}{*}{ TK3 } & \multirow[t]{3}{*}{ Melakukan pengawasan kinerja } & Pekerjaan Bekisting & $\mathrm{X} 4$ & $\begin{array}{l}\text { Berjalan dengan tangan } \\
\text { kosong }\end{array}$ & IK Bekisting & Melakukan review kinerja \\
\hline & & Pekerjaan Bekisting & $\mathrm{X} 5$ & Menganggur & IK Bekisting & Melakukan review kinerja \\
\hline & & Pekerjaan Bekisting & X6 & Waktu pribadi & IK Bekisting & Melakukan review kinerja \\
\hline \multirow[t]{5}{*}{ TK4 } & \multirow[t]{5}{*}{$\begin{array}{l}\text { Memberi sanksi apabila terjadi } \\
\text { keterlambatan progress }\end{array}$} & Pekerjaan Bekisting & $\mathrm{X} 4$ & $\begin{array}{l}\text { Berjalan dengan tangan } \\
\text { kosong }\end{array}$ & SOP Pekerjaan Struktur & $\begin{array}{l}\text { Perencanaan reward \& } \\
\text { punishment yang didapatkan } \\
\text { pekerja apabila pekerjaan tercapai }\end{array}$ \\
\hline & & Pekerjaan Bekisting & $\mathrm{X} 5$ & Menganggur & SOP Pekerjaan Struktur & $\begin{array}{l}\text { Perencanaan reward \& } \\
\text { punishment yang didapatkan } \\
\text { pekerja apabila pekerjaan tercapai }\end{array}$ \\
\hline & & Pekerjaan Bekisting & $\mathrm{X} 6$ & Waktu pribadi & SOP Pekerjaan Struktur & $\begin{array}{l}\text { Perencanaan reward \& } \\
\text { punishment yang didapatkan } \\
\text { pekerja apabila pekerjaan tercapai }\end{array}$ \\
\hline & & Pekerjaan Pengecoran & $\mathrm{X} 17$ & Menganggur & SOP Pekerjaan Struktur & $\begin{array}{l}\text { Perencanaan reward \& } \\
\text { punishment yang didapatkan } \\
\text { pekerja apabila pekerjaan tercapai }\end{array}$ \\
\hline & & Pekerjaan Pengecoran & X18 & Waktu pribadi & SOP Pekerjaan Struktur & $\begin{array}{l}\text { Perencanaan reward \& } \\
\text { punishment yang didapatkan } \\
\text { pekerja apabila pekerjaan tercapai }\end{array}$ \\
\hline \multirow[t]{2}{*}{ TK5 } & \multirow[t]{2}{*}{$\begin{array}{l}\text { Membuat penjadwalan pada } \\
\text { setiap pekerja }\end{array}$} & Pekerjaan Pembesian & $\mathrm{X} 11$ & Menganggur & SOP Pekerjaan Struktur & Membuat perencanaan SDM \\
\hline & & Pekerjaan Pembesian & $\mathrm{X} 12$ & Waktu pribadi & SOP Pekerjaan Struktur & Membuat perencanaan SDM \\
\hline
\end{tabular}


Tabel 5. Analisis Tindakan Pengembangan (Lanjutan)

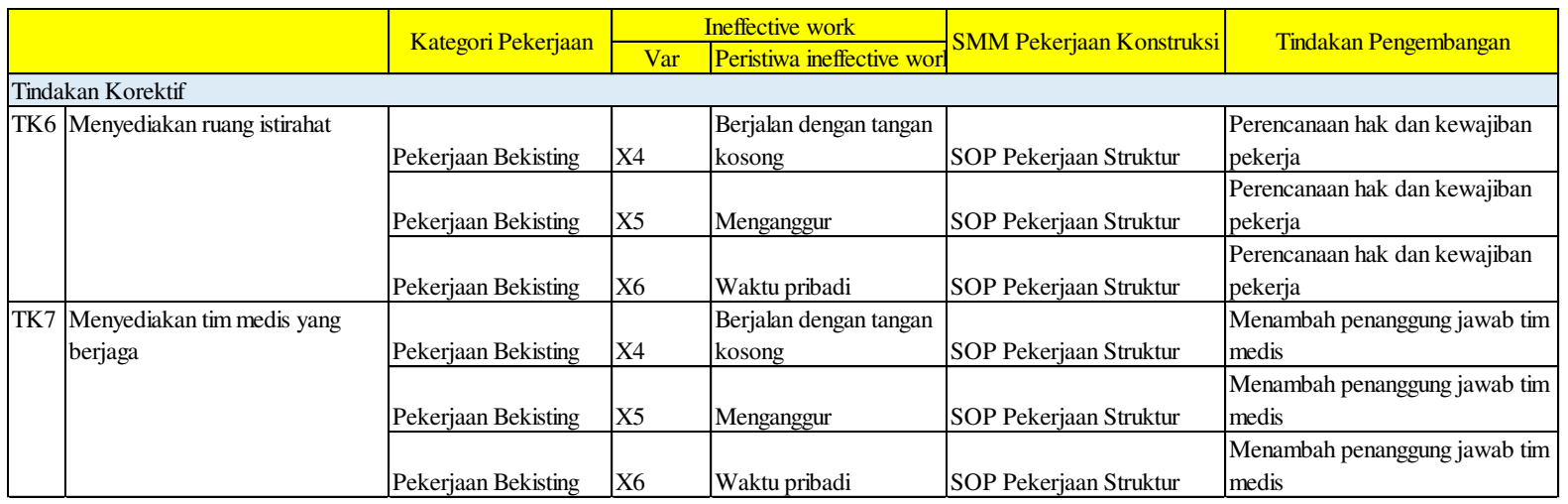

Sistem Manajemen Mutu yang dikembangkan ini berdasarkan aktivitas dari respon tertinggi. Tindakan pengembangan SMM selanjutnya terdiri dari SOP Pekerjaan Struktir, IK Bekisting, IK Pembesian, IK Pengecoran.

\section{KESIMPULAN DAN SARAN}

Kinerja pekerja struktur beton dikatakan baik apabila kegiatan ineffective work dapat terjadi seminimal mungkin. Sistem manajemen mutu berbasis ineffective work disusun karena kaitannya antara ineffective work dengan capaian nilai produktivitas kinerja. Oleh karena itu, evaluasi berbasis ineffective work merupakan sebuah metode yang tepat yang dapat digunakan untuk mengembangkan sistem manajamen mutu pekerjaan struktur beton pada proyek Padina Soho \& Residence.

Berikut ini adalah beberapa saran yang diusulkan untuk penelitian selanjutnya yaitu penelitian ini ditinjau hanya dari sudut pandang proyek Padina Soho \& Residence sebagai owner sehingga pada penelitian berikutnya dapat dilakukan dari sudut pandang yang berbeda, seperti melalui sudut pandang pemerintah. Selain itu untuk penelitian berikutnya dapat dilakukan pada seluruh proyek di Indonesia serta perlu dilakukan identifikasi aktivitas untuk selanjutnya dapat ditambahkan didalam RAM/RACI.

\section{DAFTAR PUSTAKA}

[1] ...... (2013). A Guide to the Project Management Body of Knowledge (PMBOK Guide) Vol. 5th Edition, USA,

[2] Ali Jaafari. (2000). Construction Business Competitiveness And Global Benchmarking

[3] Andi. R.A. (2003). Construction Project Administration

[4] Asiya Gul. (2012). Improving Employees Performance Through Total Quality Management

[5] Chong Chiz Chzee. (2014). Service Quality Moderate TQM Practice Towards Success Of Service Performance

[6] Dale, Barrie, dan Heather Bunney (1999). Total Quality Management Blueprint. Oxford: Blackwell

[7] Daniel I. Prajogo. (2002). The Relationship Between TQM Practices, Quality Performance, And Innovation Performance

[8] Ervianto W.I. (2003). Manajemen Proyek Konstruksi

[9] Gasperzs V. (2000). Manajemen Produktivitas Total Strategi Peningkatan Produktivitas Bisnis Global

[10] Kresna F., Simanihuruk, B.,\& Dewita, H. (2016). Produktivitas Pekerja Bekisting dan Pembesian Mneggunakan Metode Work Sampling pada Proyek Gedung 
[11] Murodif A. (2016). Pengukuran Produktivitas Dan Faktor-Faktor Yang Mempengaruhi Dalam Pembangunan Gedung Menara Sentraya Jakarta

[12] Musran Munizu. (2013). The Impact of Total Quality Management Practices towards Competitive Advantage and Organizational Performance: Case of Fishery Industry in South Sulawesi Province of Indonesia, Pakistan Journal of Commerce and Social Science

[13] Musran Munizu, Ubud Salim, Solimun. (2012). Pengaruh Praktik Total Quality Management (TQM) terhadap Budaya Kualitas, Daya Saing dan Kinerja Perusahaan (Studi pada Industri Manufaktur di Kota Makassar)

[14] OECD. (21016). Procurement-Key Performance Indicator 
JURNAL FORUM MEKANIKA

Vol. 7, No. 2, November 2018, P-ISSN 2356-1491, E-ISSN xxxx-xxxx 